\title{
IDENTIFICATION OF TRANSITIONAL SPACE AND ACTIVITY SPACE ON LINEAR URBAN SPACE (CASE STUDY: DI. PANJAITAN STREET AND KH. ALI MAKSUM STREET)
}

\author{
Ani Hastuti ARTHASARI', Rhisa Aidilla SUPRAPTO ${ }^{2}$
}

DOI: 10.21163/GT_2020.151.19

\begin{abstract}
:
The increasingly congested road conditions as a result of the development and growth of the city led to meetings and clashes of various activities and interests of users. They caused the decline of urban space quality. The primary function of the road, which does not only as a transitional space, to accommodates traffic flows complicated ways, but it can also have functioned as a space for activities for the citizens of the city. This paper aims to identify the road functions based on the users' movement and to identify the capacity of the activity space and transitional space. By using inductive qualitative methods, clear identification of road use as a transitional space and activity space obtained on DI. Panjaitan Street and KH. Ali Maksum Street. It can be used as direction recommendations for improving the quality of the road to be more human and as an effort to enhance the quality of the city.
\end{abstract}

Key-words: Urban Space, Activity Space, Transitional Space, Geography

\section{INTRODUCTION}

The cities growth occurs due to population growth, urbanization, industrialization, and globalization. On the other hand, are less responsive to the design of the city almost always causes urban degradation. One that is easy to see is the increasingly crowded road conditions, meetings, and clashes of various activities and interests of users, thus causing the quality of urban space to decline.

Many urban planners supposed that roads were only as traffic infrastructure and only transition space. If it is planned based on that alone, opportunities for using the street as space for activities closed (Budiharjo, 2006).

The primary function of the road is correct as a vehicle and pedestrian transportation lane. Nevertheless, in Yogyakarta City, many roads found as a place for the social and economic activities of its citizens. This is a small part of the human geography aspect that needs to be considered so that urban degradation does not occur.

The study of human geography also learns about the movement which is known as migration on territorial planning. On a smaller scale, on urban planning, it can be described as transition, where the space known as transitional space.

Large and medium cities such as Yogyakarta, Semarang, and Solo, roads were not merely functioning as a transitional space that accommodating the traffic flow of people movement. Those cities also have worked as an activity space such as open space for social contact, a place for ceremonial activities, recreation, and even outdoor trading activities (Budiharjo, 2006).

\footnotetext{
1,2, Universitas Amikom Yogyakarta, Faculty of Science and Technology, 55283 Yogyakarta,
} Indonesia, Corresponding author: arthasari@amikom.ac.id 
The need for roads as an activity space causes road quality fulfillment needs for its users. It can also be interpreted that the road, including pedestrian paths, are required to be able to accommodate the activities of its users so that they can carry out activities comfortably and can create a humane city for the residents. Beside, human communities are formed considering the transportation network. This confirms that there is corelation between activity and space for transportations (Magyari-Saska, 2019).

Thus the identification of road functions needs to be made seen from the activity of its use. Furthermore, those clear recommendations obtain or improving the quality of the use of roads that are more humane as well as efforts to improve the quality of the city. And the better environmental quality could be enhanced by the existence of the concept of sustainable urban lanscape aspect regarding social, economic, and ecological. (Soemardiono, et al., 2019)

The issues of this research are (1) how is the road function condition if seen from the activity of its users, and (2) how is the capacity of the activity space and transitional space in the linear urban space?

\section{STUDY AREA}

This research located in a part of DI. Panjaitan Street Yogyakarta and KH. Ali Maksum Street Bantul. It is a road corridor situated on the south side of the imaginary axis of Yogyakarta. This axis as an axis of philosophy, covers Tugu Pal Putih, Kraton Yogyakarta, and Panggung Krapyak.

DI. Panjaitan Street and KH. Ali Maksum Street is on the southernmost axis in this imaginary axis. Administratively, DI. Panjaitan Street is included in the Yogyakarta City area, while KH. Ali Maksum Street is part of the Bantul Regency.

Overall DI. Panjaitan Street is the road from Plengkung Gading extending to the south. But in this case, the focus of the object of research is a section of the road starting at the junction of Jogokariyan Street.

DI. Panjaitan Street is an area along sections A and B (Fig. 1), but the selected area for the study is in section B. This is because section B

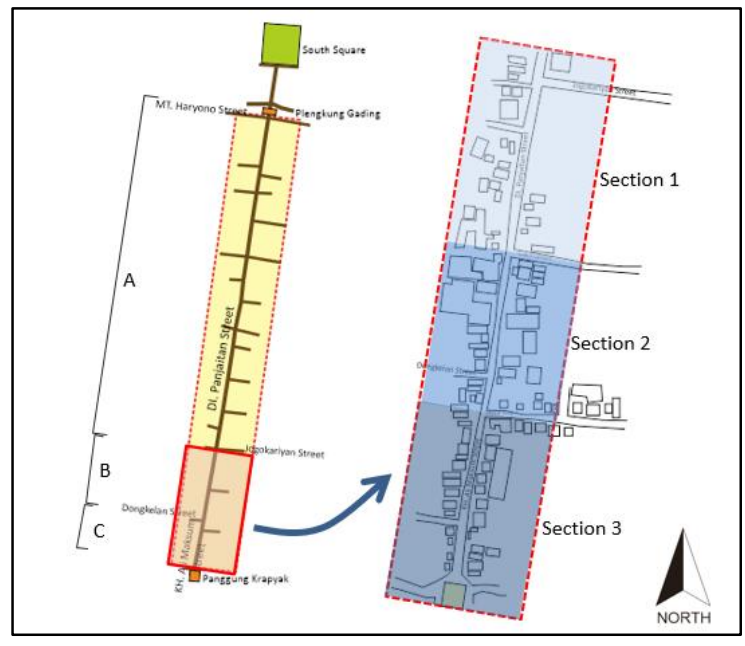

Fig. 1. Research Area Limits has more road activity to be observed than in section A. While section $\mathrm{C}$ is part of $\mathrm{KH}$. Ali Maksum Street, which is also part of the focus of the research area. This section becomes essential because it is a continuous road from DI. Panjaitan Street up to the starting point of the southern imaginary axis, namely the Panggung Krapyak.

From the B and C sections, it divided again into 3 (three) fragments, namely:

1. Section 1: extending from the junction of Jogokariyan Street to the intersection of Cuwiri Street, is part of DI. Panjaitan Street Yogyakarta.

2. Section 2: extending from the junction of Cuwiri Street to the intersection of Dongkelan Street, is part of DI. Panjaitan Street Yogyakarta. 
3. Section 3: extending from the intersection of Dongkelan Street to the Panggung Krapyak, is part of KH. Ali Maksum Street.

\section{METHODOLOGY}

This research approach is inductive and using qualitative methods, which implemented to build knowledge through meaning and discovery (Danim, 2002:36).

The main characteristic of qualitative research (abstracted from Danim, 2002): (1) Direct data sources in the form of natural situation management and researchers become the main instruments, (2) Descriptive, that is, data collected in the form of words, images, not numbers. Even if there are numbers, they are only as support. (3) It emphasizes the work process rather than results. The method which all phenomena encountered, translated to daily activities. (4) Data analysis is inductive, and abstractions arranged based on data that had collected and grouped through data collection during fieldwork at the research site, (5) Emphasize meaning, namely, the focus of the study directly linked to the problems of human life.

The process of collecting data and information is carried out directly in the observation area to get more information about activities, enclosures, and the architectural elements in the study area - the execution time not bound by certain days and hours. However, the observation was conducted on three-time frames a day, namely in the morning, afternoon, late afternoon, and evening. And it was held in a few days until the data is saturated. It had done to ensure the validity of the information obtained.

In collecting data, required instruments include stationary, drawing tools, and camera. Stationary and drawing tools used to draw spatial sketches while observing in the fields of study. The camera used to record physical conditions and other things that support the research implementation.

\section{RESULTS AND DISCUSSIONS}

The results of observations of the physical condition of linear city space in the study area in parts 1,2 and 3 are as follows.

1. The general terms of Section 1 are : (1) On the west side, the road shoulder is in the form of land without pavement, (2) On the east side there are parks and quite wide space sidewalks (pedestrian ways), (3) There is a separation space between pedestrians and vehicles.

2. The general conditions of Section 2 are : (1) Both on the west and east side has concrete paved shoulders, (2) there are no sidewalks as pedestrian ways, (3) The separation space between pedestrians and vehicles is not clear.

3. The general conditions of Section 3 are : (1) Both on the west and east side has concrete paved shoulders that are narrower than Section 2, (2) there is no sidewalks as pedestrian ways, (3) The separation space between pedestrians and vehicles is not clear.

In addition to observing the physical condition of linear urban space, the author also notes the activities that occur. Several criteria affect the analysis of the setting of activity behavior, that is, person, standing pattern of behavior, physical milieu, zygomorphic, territory, and temporal (Hartono, 2017).

This research will not be discussed thoroughly on the six criteria. However from the six principles will be taken the basic things that can use in observation, namely: (1) users, 
including pedestrians and motorists, (2) repeated activities that occur in the area observations, (3) physical boundaries, which defined as enclosures within the observation area.

The results of observations on activities and enclosures in the observation area is presented in Table 1.

Table 1.

The results of observations at Section 1.

\begin{tabular}{|c|c|c|c|c|}
\hline Area & Observation & East Side & Street & West Side \\
\hline \multirow{3}{*}{ 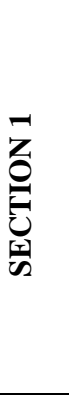 } & Activity & $\begin{array}{l}\text { Street vendors on the } \\
\text { path-space (shoulder of } \\
\text { the road), throughout } \\
\text { the day, there was a } \\
\text { change in the type of } \\
\text { street vendors, and stay } \\
\text { longer. }\end{array}$ & $\begin{array}{l}\text { Street vendors on the } \\
\text { path-space (shoulder } \\
\text { of the road), moving, } \\
\text { dinamic. }\end{array}$ & $\begin{array}{l}\text { Street vendors tend } \\
\text { to not exist, } \\
\text { sidewalks are also } \\
\text { used for parking }\end{array}$ \\
\hline & Enclosure & $\begin{array}{l}\text { permanent fence, shade } \\
\text { tree }\end{array}$ & $\begin{array}{l}\text { Bottom enclosure: } \\
\text { asphalt pavement }\end{array}$ & $\begin{array}{l}\text { Trees, building } \\
\text { facades. }\end{array}$ \\
\hline & Element & $\begin{array}{l}\text { Trees, electric poles, } \\
\text { street lights. }\end{array}$ & - & $\begin{array}{l}\text { Trees, electric } \\
\text { poles, street lights. }\end{array}$ \\
\hline \multirow{3}{*}{$\overbrace{\substack{c \\
\hdashline}}^{n}$} & Activity & $\begin{array}{l}\text { Street vendors on the } \\
\text { path-space (shoulder of } \\
\text { the road), moving, } \\
\text { dinamic. }\end{array}$ & $\begin{array}{l}\text { Street vendors on the } \\
\text { path-space (shoulder } \\
\text { of the road), moving, } \\
\text { dinamic }\end{array}$ & $\begin{array}{l}\text { Street vendors on } \\
\text { the path-space } \\
\text { (shoulder of the } \\
\text { road), moving, } \\
\text { dinamic. }\end{array}$ \\
\hline & Enclosure & $\begin{array}{l}\text { Fence with doors, } \\
\text { shade tree }\end{array}$ & $\begin{array}{l}\text { Bottom enclosure: } \\
\text { asphalt pavement }\end{array}$ & $\begin{array}{l}\text { Trees, building } \\
\text { facades. }\end{array}$ \\
\hline & Element & $\begin{array}{l}\text { electric poles, street } \\
\text { lights. }\end{array}$ & - & $\begin{array}{l}\text { Trees, electric } \\
\text { poles, street lights. }\end{array}$ \\
\hline \multirow{3}{*}{$\underbrace{N}_{\substack{c \\
\hdashline}}$} & Activity & $\begin{array}{l}\text { Street vendors on the } \\
\text { path-space (shoulder of } \\
\text { the road), moving, } \\
\text { dinamic }\end{array}$ & $\begin{array}{l}\text { Street vendors on the } \\
\text { path-space (shoulder } \\
\text { of the road), moving, } \\
\text { dinamic }\end{array}$ & $\begin{array}{l}\text { Street vendors on } \\
\text { the path-space } \\
\text { (shoulder of the } \\
\text { road), moving, } \\
\text { dinamic }\end{array}$ \\
\hline & Enclosure & $\begin{array}{l}\text { Fence with doors, } \\
\text { building facades }\end{array}$ & $\begin{array}{l}\text { Bottom enclosure: } \\
\text { asphalt pavement }\end{array}$ & $\begin{array}{l}\text { Trees, building } \\
\text { facades. }\end{array}$ \\
\hline & Element & $\begin{array}{l}\text { electric poles, street } \\
\text { lights. }\end{array}$ & - & $\begin{array}{l}\text { electric poles, street } \\
\text { lights. }\end{array}$ \\
\hline
\end{tabular}

In the observation capacity of transitional space and activity space in linear urban space, using parameters as a limitation on capacity measurement. They can be used to assess linear urban space in its use as a transitional space and activity space. These parameters are as follows:

1. Linear urban space as a transitional space:

a. The road is only a transitional space, connectors that are bypassed to go to one space to another.

b. The vehicle only drove, the driver did not stop to perform activities on the roadside,

c. Pedestrians only pass, do not stop to do urban activities.

d. The greater the use as a transitional space, the road function as a circulation path is visible. 
2. Linear urban space as an activity space:

a. The vehicle stops to do activities in the road space, for example, buying and selling businesses.

b. Pedestrians use street space and pedestrian paths to carry out activities, such as chatting, buying, and marketing.

c. The higher the use as an activity space, then the more significant the streets and pedestrians using pathways as a place for the activities of the urban community, both the main event, additional activity, and social activity.

The relationship between the capacity of the transition space and the activity space can be seen in Fig. 2.

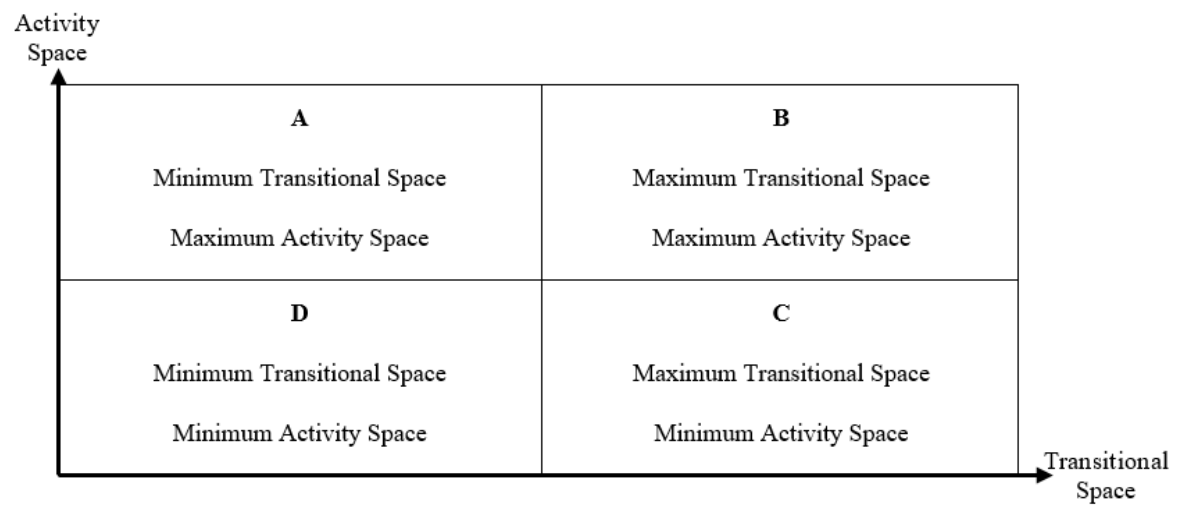

Fig. 2. Capacity Relationship Diagram of Transitional and Activity Space

The results of the observation of the transitional space and activity space in Section 1, 2, 3 are shown in the following table.

Table 2.

The results of observations on Transitional and Activity Space.

\begin{tabular}{|c|c|c|c|}
\hline Observation & East Side & Street & West Side \\
\hline \multirow[t]{2}{*}{ Section 1} & $\begin{array}{l}\text { The vehicle stops for } \\
\text { drivers to do activities in } \\
\text { the road space, namely } \\
\text { buying and selling } \\
\text { activities, sometimes also } \\
\text { chatting. Pedestrians also } \\
\text { do the same activity. }\end{array}$ & $\begin{array}{l}\text { The vehicle only } \\
\text { drove, the driver } \\
\text { did not stop in this } \\
\text { area. }\end{array}$ & $\begin{array}{l}\text { The vehicle only drove, } \\
\text { the driver did not stop to } \\
\text { perform activities on the } \\
\text { roadside. Sidewalks are } \\
\text { also used for parking }\end{array}$ \\
\hline & $\begin{array}{l}\text { Minimum Transitional } \\
\text { Space (T min) } \\
\text { Maximum Activity Space } \\
\text { (A max) }\end{array}$ & $\begin{array}{l}\text { Maximum } \\
\text { Transitional Space } \\
\text { (T max) } \\
\text { Minimum Activity } \\
\text { Space (A min) }\end{array}$ & $\begin{array}{l}\text { Maximum Transitional } \\
\text { Space (T max) } \\
\text { Minimum Activity Space } \\
(\text { A min) }\end{array}$ \\
\hline Section 2 & $\begin{array}{l}\text { Many vehicles just drove. } \\
\text { Many pedestrians just } \\
\text { pass by. } \\
\text { There are also many } \\
\text { community activities } \\
\text { along the way. }\end{array}$ & $\begin{array}{l}\text { The vehicle only } \\
\text { drove, the driver } \\
\text { did not stop in this } \\
\text { area. }\end{array}$ & $\begin{array}{l}\text { Many vehicles just drove. } \\
\text { Many pedestrians just } \\
\text { pass by. } \\
\text { There are also many } \\
\text { community activities } \\
\text { along the way. }\end{array}$ \\
\hline
\end{tabular}




\begin{tabular}{|c|c|c|c|}
\hline Observation & East Side & Street & West Side \\
\hline & $\begin{array}{l}\text { Maximum Transitional } \\
\text { Space (T max) } \\
\text { Maximum Activity Space } \\
\text { (A max) }\end{array}$ & $\begin{array}{l}\text { Maximum } \\
\text { Transitional Space } \\
\text { (T max) } \\
\text { Minimum Activity } \\
\text { Space (A min) }\end{array}$ & $\begin{array}{l}\text { Maximum Transitional } \\
\text { Space (T max) } \\
\text { Maximum Activity Space } \\
\text { (A max) }\end{array}$ \\
\hline \multirow[t]{2}{*}{ Section 3} & $\begin{array}{l}\text { Many vehicles just drove. } \\
\text { Many pedestrians just } \\
\text { pass by. } \\
\text { There are also many } \\
\text { community activities } \\
\text { along the way. }\end{array}$ & $\begin{array}{l}\text { The vehicle only } \\
\text { drove, the driver } \\
\text { did not stop in this } \\
\text { area. }\end{array}$ & $\begin{array}{l}\text { Many vehicles just drove. } \\
\text { Many pedestrians just } \\
\text { pass by. } \\
\text { There are also many } \\
\text { community activities } \\
\text { along the way. }\end{array}$ \\
\hline & $\begin{array}{l}\text { Minimum Transitional } \\
\text { Space (T min) } \\
\text { Maximum Activity Space } \\
\text { (A max) }\end{array}$ & $\begin{array}{l}\text { Maximum } \\
\text { Transitional Space } \\
\text { (T max) } \\
\text { Minimum Activity } \\
\text { Space (A min) }\end{array}$ & $\begin{array}{l}\text { Maximum Transitional } \\
\text { Space (T max) } \\
\text { Maximum Activity Space } \\
\text { (A max) }\end{array}$ \\
\hline
\end{tabular}

There are two ways to define the function of the space, street-side for vehicles, and shoulder or pathways for the pedestrian. This is the first reasoning to discuss the capacity of transitional space and activity space also the types of road function.

The condition in Section 1 can be seen in Fig. 3.

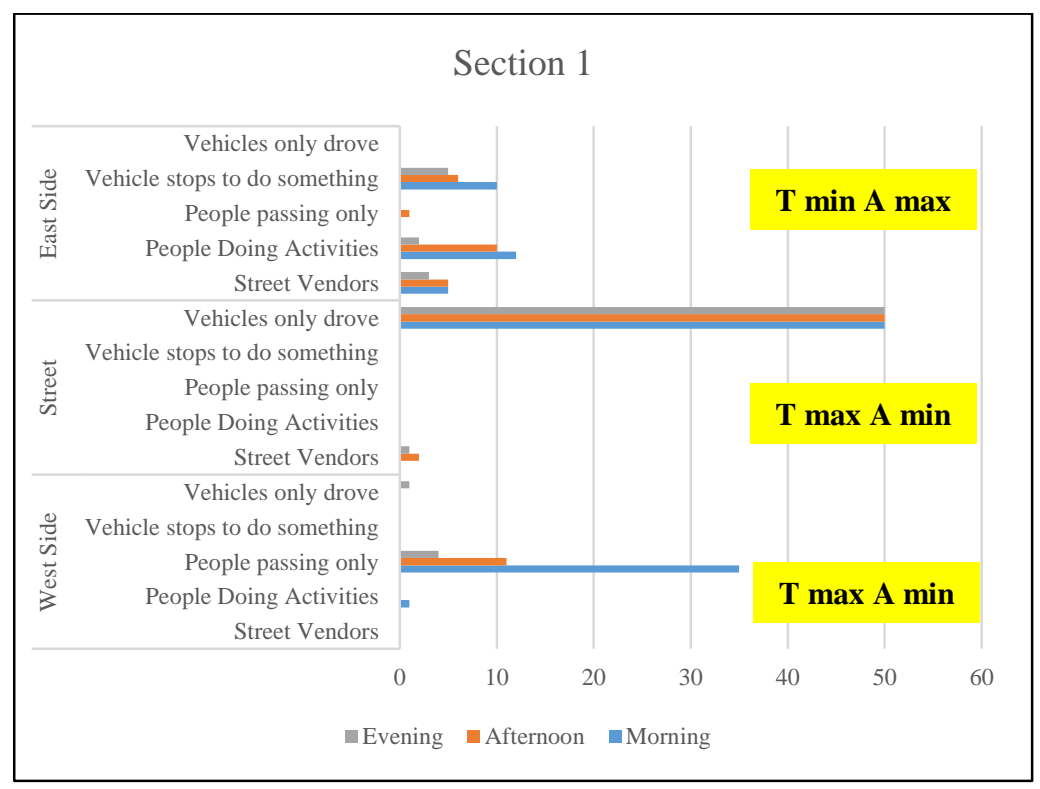

Fig. 3. Activities of Pedestrian and Vehicles at Section 1

In Section 1, the east side which is not a space for vehicles, but in fact, it is used for vehicle stops to do some activities. This is reducing the number of pedestrians using space to transition, but there is a lot of activity in the space. Causing the function of the road to be 
disguished. Whereas on streetside, only vehicles that use as a transition space, there are no people passing and activities, so that makes the clear function of the road. At Westside, which is for pedestrian space, it is indeed using the space as a transitional space for pedestrians, so that causing the clear function as a pathway.

The condition in Section 2 can be seen in Fig. 4 while in Section 3 can be seen in Fig 5.

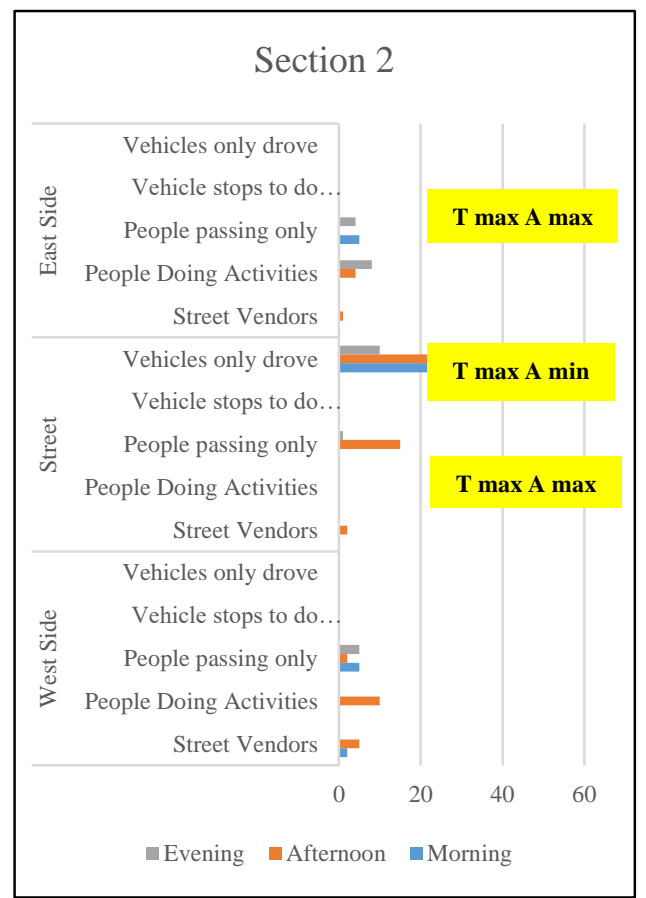

Fig. 4. Activities of Pedestrian and Vehicles at Section 2

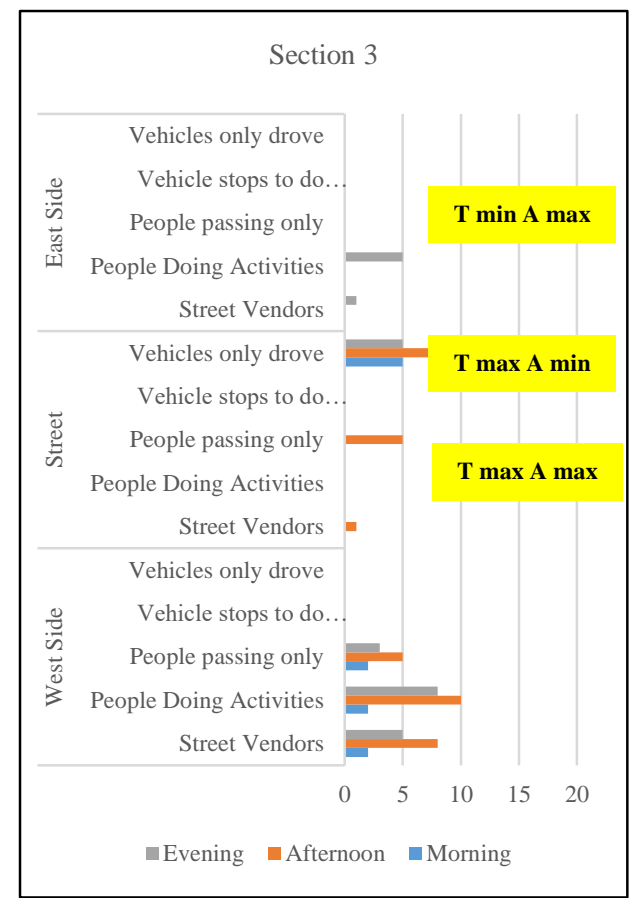

Fig. 5. Activities of Pedestrian and Vehicles at Section 3

In Section 2, both east side and west side as pedestrian ways, indeed used as a transitional space for pedestrians, but a lot of activities occur, causing a mixed-function to emerge, namely between the activity space and the transitional space. Whereas on the streetside, there are vehicles and a number of pedestrians who pass and function it as a transitional space, resulting in a mixed-function, which is between road users.

It can be shown at Fig 5 that in Section 3, there is no enough space for pedestrian ways, causing disguished function. Whereas on the streetside, there are vehicles and a number of pedestrians who pass and function as a transitional space, resulting in a mixed-function, which is between road users. Exactly the same at the streetside in Section 2. On the west side which is indeed for pedestrian roads, it is indeed used as a transitional space for pedestrians, but there is a lot of activity, which causes a mixed-function, which is between the activity space and the transition space.

Observations in each section of the observation area can be grouped in the matrix of the relationship between the transitional space and the activity space (Fig. 6) 


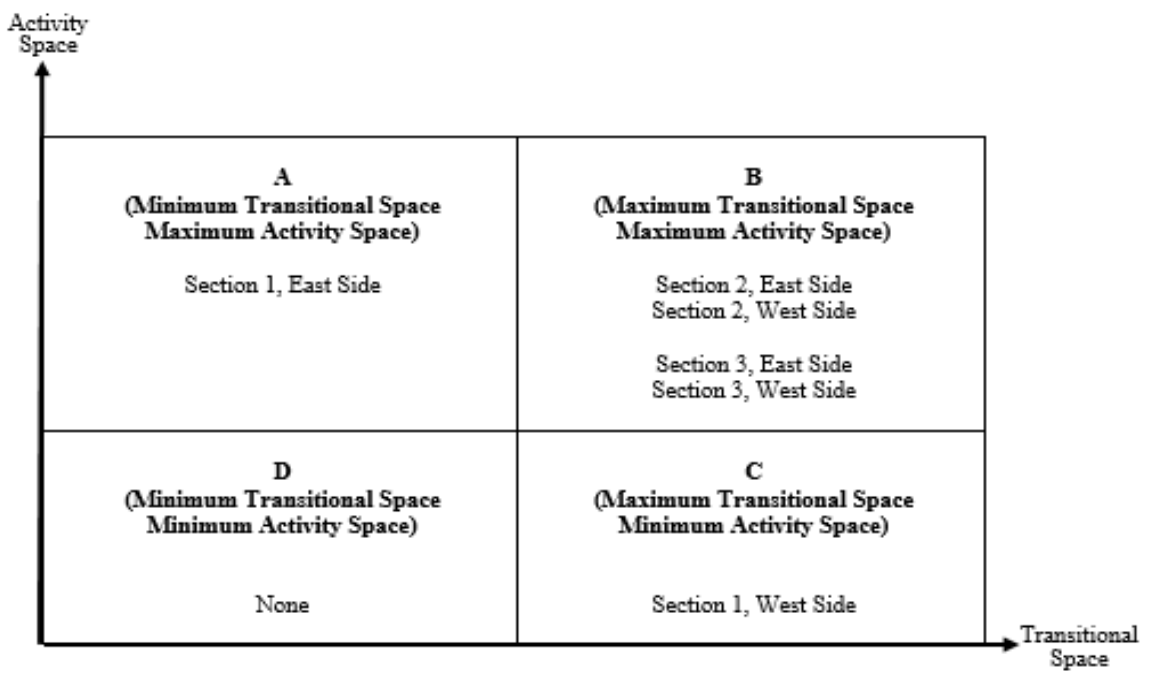

Fig. 6. Diagram of Condition of Observation Area Seen From the Relationship between Transitional Space and Activity Space

From the results of field observations obtained the following results:

1. The size of the activity space in linear space influenced by (1) favorable conditions of the space enclosure and (2) the space dimension.

2. There are three types of relationship between activity space, transitional space, and linear urban space, as illustrated in the following diagram.

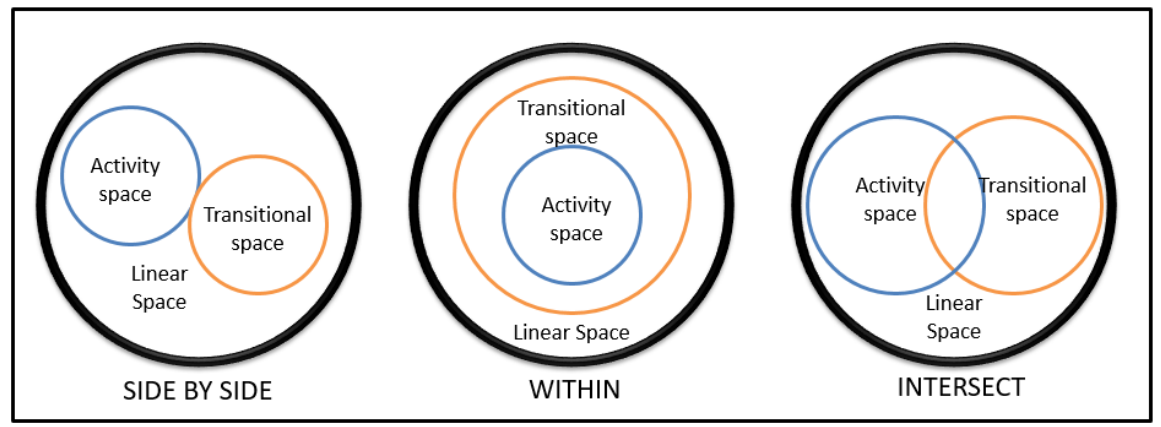

Fig. 7. Types of Relationship between Activity Space and Transitional Space in Linear Urban Space

3. There is no area has a minimum of transition space and activity space (Fig. 6), meaning that the observed area is a quite crowded urban space.

4. Two of the three beheaded areas, namely Section 2 and Section 3, have the same maximum transitional and activity space, meaning that from the positive side, the use of linear urban space on DI Panjaitan Street and KH. Ali Maksum Street is always active. But from the negative side, there will be a mixture of activities and circulation in the same space, which can trigger urban space clutter. 
5. The capacity of activity space, transitional space, and dimensions can affect the types of street functions, including streets with precise functions (only as a circulation way), roads with disguised features, and roads with mixed services.

6. All of the observation results could define in one diagram, which illustrates the capacity of space as an activity space and a transitional space in the connections between the types of space, including the road function and the pedestrian ways existence. The figure below is showing those connections.

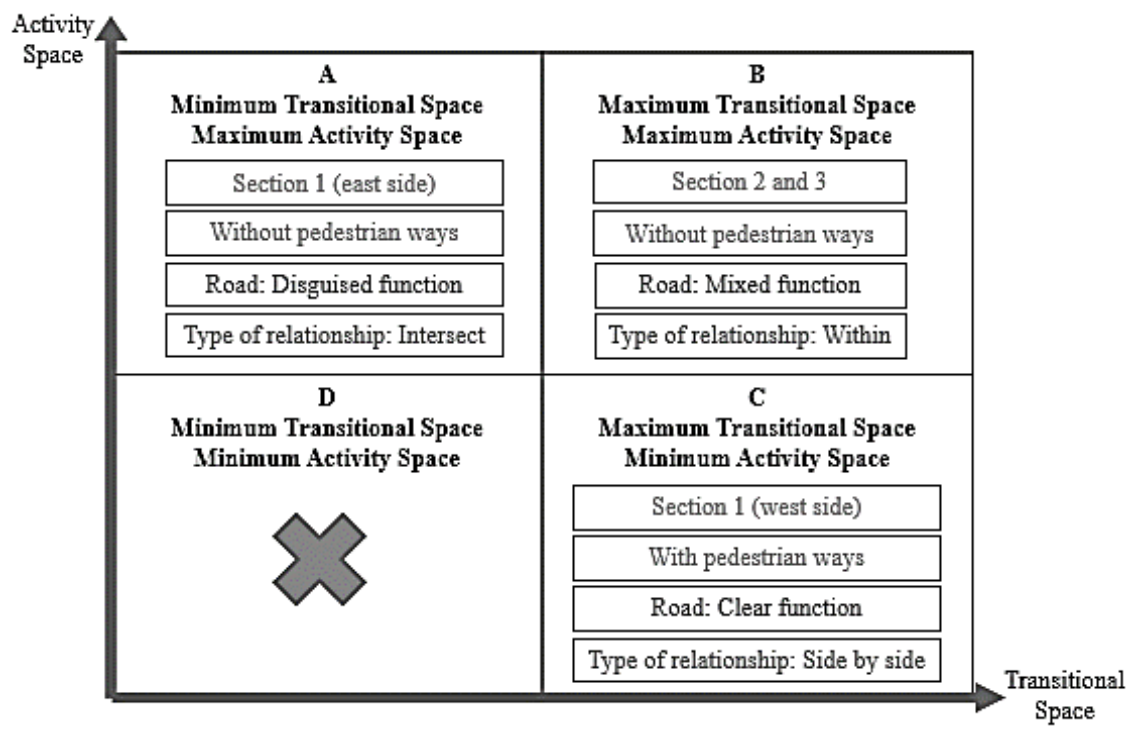

Fig. 8. The connections of the results

\section{CONCLUSIONS}

This paper has discussed the conditions of activity space and transitional space influenced by users of space, repeated activities that occur in the area observations, also enclosure and space elements. Each can not be separated from the influence of dimensions and the space enclosure. It found that road function allotment more clearly defines as transitional space if the activities occur on it are minimum (minimum activity space capacity). Then, the road will have a mixed-function when accommodating movement and transition on the same space (both activity space and transitional space capacities are maximum). It also can be interpreted that maximum activity space is obtained if the use of activity space within or intersect with transitional space (mixed-used space). Based on the observation, linear urban space could stay active and comfortable by maximizing or clearing up the allotment (function) of the space and by placing the appropriate space enclosures and space elements.

\section{R E F E R E N C ES}

Alwasilah, A. C. (2003) Just Qualitative: Basics of Designing and Conducting Qualitative Research, Jakarta.

Budiharjo, E., et.al. (2005) Sustainable Cities, P.T. Alumni Publishing, Bandung 
Budihardjo, E. (2006) Problem Spark on Architecture, Housing and Urban, Gadjah Mada Univesity Press, Yogyakarta.

Danim, S. (2002) Become a Qualitative Researcher: Methodologies, Presentations, and Publication for Students and Beginner Researchers in the Social Sciences, Education and Humanities, Bandung.

Hantono, D. (2017) Public Open Space Activities Patterns in Fatahillah Park Area Jakarta, Komposisi v. 11, n. 6, Retrieved from https://www.researchgate.net/publication/320755544.

Haryadi \& Setiawan, B. (1995), Environmental and Behavioral Architecture; An Introduction to Theory, Methodology and Application, Development Preject of the Center for Environmental Studies at the Directorate of Higher Education Ministry of Education and Culture of the Republic of Indonesia.

Law of the Republic of Indonesia Number 38 of 2004 concerning Roads

Magyari-Saska, Z. (2019) Road Network Based Community Detection, Case Study for an Eastern Region of Austro-Hungarian Monarchy, Geographia Technica, 14 (1), 82-91.

Mirsa, R. (2012), City Spatial Elements, Graha Ilmu, Yogyakarta.

Rahmiati, D. (2017) Study of the Forming Elements of Urban Space in Urban Open Public Spaces (Case Study: Karanganyar Square), Ikraith-Teknologi, v. 1, n. 2, Palembang.

Singh, R. (2015) Understanding Transition Spaces, Importance and Role in Indian Architecture, Sushant School of Art and Architecture, Retrieved from https://www.academia.edu/19852235/Understanding_Transition_Spaces

Subiyantoro, H. (2006) Transitional Space As An Aesthetic Formers of Space Composition, National Seminar on Planning Engineering VI: Opportunities for Bachelor of Architecture in Interior Design, $\quad$ Retrieved from https://www.researchgate.net/profile/Heru_Subiyantoro2/publication/323725922.

Soemardiono B., Rachmawati M., Ardianta D.A., Nugroho S. (2019), Spatial Analysis of Urban Dense Area in Developing Criteria Design Based on People Participation: Case Study of Kembang Jepun, Surabaya, Geographia Technica, v. 14 (Special Issue), 13-21.

Sunaryo, R.G. (2010) Changes in Space Settings and Public Activity Patterns in UGM Campus Open Space, National Seminar on Architecture Research and Planning 1: Humanism, Architecture and Planning, Retrieved from http://repository.petra.ac.id/15515/1. 